\title{
Volunteer Motivations at the 2012 Super Bowl
}

\author{
Jennifer L. VanSickle \\ Department of Kinesiology, \\ University of Indianapolis, Indianapolis, Indiana, USA \\ David A. Pierce \\ Department of Kinesiology, \\ Indiana University-Purdue University Indianapolis, Indiana, Indianapolis, USA \\ Michael Diacin \\ Department of Kinesiology, \\ University of Indianapolis, Indianapolis, Indiana, USA
}

\begin{abstract}
Purpose
The purpose of this paper is to examine mega-event volunteers' motivations and their impact on volunteer satisfaction. Additionally, this study investigated motivational differences between volunteers based upon four demographic variables: age, gender, educational level, and income.

\section{Design/methodology/approach}

A modified version of the Volunteer Motivations Scale for International Sporting Events (Bang and Chelladurai, 2009) was administered to 8,000 Super Bowl volunteers via Survey Monkey with the permission of the Indiana Sports Corporation. In all, 24 percent $(n=1,928)$ of the volunteers completed the survey. Exploratory factor analysis was used to reduce the survey questions into a smaller number factors. Multivariate analysis of variance was utilized to compare differences in the four demographic variables on the factors. Multiple regression was used to predict satisfaction on the basis of the four factors.
\end{abstract}

\section{Findings}

Volunteers were motivated by four factors: Community Support, Love of Sports, Personal Growth, and Career Development. These four factors all significantly predicted satisfaction with the volunteer experience. The overall MANOVA was significant and revealed that ten of 16 group comparisons possessed significant differences. Females rated Community higher than males, while males rated Love of Sports higher than females. Older volunteers and those with higher household incomes were motivated more by Community Support, while younger volunteers and those with lower incomes were motivated by Career Development. Likewise, less educated volunteers placed a higher value on Career motivations than more educated volunteers who placed a high value on Personal Growth.

\section{Research limitations/implications}

Dissatisfied volunteers may have chosen to not participate in the study. Follow-up interviews with dissatisfied volunteers might provide insight for event organizers that would shed light on factors that influence retention and recidivism.

\section{Practical implications}

The findings of this study suggest that mega sport volunteer managers should recognize that motivational differences among volunteers do exist and utilize this information for creating recruitment materials targeted to specific groups. Then volunteers can be assigned to tasks that tap into their desire, thus enhancing potential volunteer satisfaction and their return as a volunteer at future events.

\section{Originality/value}

This study was conducted in the context of America's largest mega event in a city that hosted the event for the first time. In addition to collecting one of the largest number of responses for volunteers at megasporting events, the development of the Community Support factor was unique within the context of this study. The Community Support factor was rated as the most important by volunteers and tied to other questions such as wanting to help make the event a success, helping others, and creating a better society.

This is the author's manuscript of the article published in final edited form as:

VanSickle, J. L., Pierce, D. A., \& Diacin, M. (2015). Volunteer motivations at the 2012 Super Bowl. International Journal of Event and Festival Management, 6(3), 166-181. http://dx.doi.org/10.1108/IJEFM-12-2014-0029 
This indicates that volunteers had pride in their community and wanted to help the event be successful by helping the city's visitors.

\section{Keywords:}

Satisfaction, Motivation, Volunteer management, Event management, Mega event, Super Bowl

\section{Acknowledgments:}

The authors would like to acknowledge the Indiana Sports Corporation for their participation in the study.

Hosting mega sporting events creates a unique challenge for cities and nations. The cost of hosting mega sporting events like the NFL Super Bowl, Olympics Games, and FIFA World Cup are substantial and continue to rise. In 2012 Indianapolis spent approximately \$25 million to host Super Bowl XLVI (Woolley and Steverman, 2012) while London spent approximately \$20 billion to host the 2012 Olympics Games (Van Riper, 2012). The expense associated with hosting such large events is offset by the major media exposure, visitor spending, and economic activity generated (Hiller, 2000). Cities and nations actively pursue these mega events for the potential economic rewards and notoriety they bring to the area (Malfas et al., 2004). According to Horne (2007), mega events have significant consequences for the host city or nation and generate considerable media coverage. While the Olympic Games and FIFA World Cup are the two most widely mentioned mega sporting events, the popularity and spectacle of the NFL Super Bowl has driven it to the ranks of a mega event as defined by Horne.

The aforementioned large sums spent on mega events do not include expenditures for the majority of human resources required to stage these large events. Instead, mega events rely heavily on free labor provided by volunteers to relieve budget pressures and reduce costs (Shin and Kleiner, 2003; Strigas and Jackson, 2003). Mega sporting events would not be feasible without volunteers who assist with security, technical support, supervision, and event organization (Green and Chalip, 1998; Twynam et al., 2003). 
Consequently, mega sporting events like the Olympics Games, FIFA World Cup, and NFL Super Bowl are not possible without the recruitment of a large number of volunteers (Elstad, 1996; Georgiadis et al., 2006; Giannoulakis et al., 2008; Green and Chalip, 2004; Twynam et al.). To illustrate the breadth and complexity of volunteer management required for a mega event like the Super Bowl, the 2012 Super Bowl in Indianapolis required 8,000 volunteers collectively working 150,000 hours of time (Jarosz, 2012).

While several researchers have investigated the motivations of volunteers at mega sporting events (Bang and Chelladurai, 2009; Green and Chalip, 2004; Georgiadis et. al., 2006; Giannoulakis et. al., 2008) a gap in the literature exists when it comes to the potential influence of demographic characteristics on volunteer motivations. Previous researchers, even while advising volunteer managers to market events based upon volunteers motivations, have failed to provide information about motivations based upon demographics, the kind of information that most marketers would ask to see. However, it is only through the recognition that volunteers are not a homogenous group of people and that volunteer motives vary among individuals, that one can develop appropriate, targeted recruitment and retention strategies (Treuren, 2014). Therefore, this research addresses this gap by investigating motivational differences based upon the volunteers' demographics.

Additionally, this research is significant because it explores the connection between volunteer motivations and satisfaction at mega-sporting events. Only twice have researchers investigated satisfaction of volunteers at mega sporting events (Green \& Chalip, 2004; Elstad, 1996). However, understanding the satisfaction of volunteers at mega sporting events is important. If the activity does not satisfy the basic motives of the 
volunteers at these mega sporting events, then recruiting the required number of volunteers would be extremely difficult (Wollebaek, Skirstad, \& Hanstad, (2012).

\section{Sport Event Volunteer Motivations}

Motives for volunteering at sporting events were initially organized into four categories and come from the work of Farrell et al. (1998) and Twynam et al. (2003). Studying volunteers at a variety of curling events, the researchers developed a questionnaire placing volunteer motives into four categories: Purposeful, Solidarity, External Traditions, and Commitments. Purposeful motives stem from a desire to positively contribute to the event and the community. Solidarity motives refer to social exchanges and acquiring practical or education experiences. External Tradition motives relate to the use of free time and family traditions. Commitment reasons involve satisfying external pressures and prestige factors. Overall, researchers found that the top motives for volunteering for these events were Purposive and included the desire to help make the event a success, doing something worthwhile, giving back to the community, and creating a better society. The lowest ranking reasons were found in the External Traditions category and included the need to fill free time or uphold a family tradition of volunteering.

Building upon the research of Farrell et al. (1998) and Twynam et al. (2003), Strigas and Jackson (2003) studied volunteers at a regional marathon and developed their own questionnaire. Their work added a fifth motivational category, called Material Rewards, concerned the rewards and incentives volunteers received from working the 
event. Like Twynam et.al. (2003) other motives centered on contributing to the event and community, relieving stress and filling free time, the need for social interaction and networking, and family traditions. Also like Twynam et al., the top rated motives for volunteering were Purposive, or to make the event a success and to make a better society. The least important motives, found in the Material category, were to gain practical experience for future employment.

Maclean and Hamm (2007), using the five dimensional model devised by Strigas and Jackson (2003), expanded the volunteer motivation research to include Love of Sport as a factor. Studying volunteers at a women's golf event, Maclean and Ham found that egoistic factors (improve my skills, interact with others, discover new interests) and leisure factors (relieve stress, good escape, feel less lonely) were the greatest motivators. This was unlike the results discovered by Farrell et al. (1998) and Strigas and Jackson. Maclean and Hamm hypothesized that the context of the volunteer experience produced the difference. By its nature, golf is a leisure activity and would draw volunteers who were motivated by leisure interests. They also found a strong relationship between Love of Sport (golf) and commitment to remain a volunteer. This could explain the prevalence of egoistic and leisure factors as top motivators. Other motivators were prestige, followed by the influence of others, working with people from different backgrounds, and relieving stress.

Recognizing the distinctive impact of mega sporting events, Bang and Chelladurai (2009) developed the Volunteer Motivations Scale for International Sporting Events (VMS-ISE). The scale included 6 categories. The first five categories, similar to previous research on sport event volunteers, included Expression of Values, Personal Growth, 
Career Orientation, Extrinsic Rewards and Interpersonal Contacts. The sixth category, labeled Patriotism, referred to pride in and love of country. For Olympic Games volunteers, helping the country gain prestige and the overall nature of event were the top motivators. Because of the nature of the event, Patriotism, as a motive for volunteering, may be unique to international competitions. Like previous studies, motives relating to careers and extrinsic rewards were the lowest rated motivators.

Acknowledging the importance of pride as a motive for volunteering, as found by Bang \& Chelladurai (2009) and the influence of Love of Sport on volunteers, as found by MacLean and Hamm (2007), Bang \& Ross’s (2009) research supported a seven dimensional model for volunteer motivations. Studying volunteers at the Twin Cities Marathon, Bang and Ross replaced the VMS-ISE category of Patriotism with Community Involvement. Community Involvement was defined as a desire to make the event a success because of love of the community and a desire for the community to gain prestige from hosting the event. Then they added Love of Sport as a seventh dimension. Community Involvement was found to be a major motivating factor for volunteers at the Twin Cities Marathon, as was Love of Sport. Other top motivators included Expression of Values (concern for others and making the event a success), and Interpersonal Contacts (meeting new people).

\section{Volunteer Motivation and Demographic Characteristics}

While previous researchers have been able to categorize and classify sport volunteers' motives, few have investigated the potential of age, gender, education and income to influence volunteer motives at sporting events. Most of the research exploring demographic differences at sporting events has focused upon differences between 
genders. One study, investigating volunteers at a professional tennis event, found no motivational differences between males and females (Pauline and Pauline, 2009). However, others have reported significant differences. Love for the sport was reported as a top motivator for males at several different sporting events including golf, gymnastics, and skiing (Wollebaek et. al., 2012; Downward et. al., 2005; Jarvis and Blank, 2011; Skirstad and Hanstad, 2013). However, females volunteering at these events were more driven by career-oriented motives (Jarivs and Blank; Skirstad and Hanstad; Wollebaek et. al.), social factors (Skirstad and Hanstad), and increasing their self-confidence (Jarvis and Blank). At mega sporting events, like the Olympic and Commonwealth Games, significant differences in motives by gender were found. Males at the Commonwealth Games cited Love of Sport as the top motivator while females reported increasing their self-confidence, enhancing their personal development and experiencing a chance of a lifetime as motivators for participating (Downward et. al.). For 2004 Olympic Games volunteers, gender differences existed in values and self-confidence, but the breakdown for gender was not reported (Georgiadis et. al., 2006).

While gender differences in motivation have been recorded, researchers have largely ignored the influence of age, educational level and income on sport event volunteers. Jarvis and Blank (2011) found that younger volunteers at the 2007 World Artistic Gymnastic Championships in Germany ranked career motives, self-interest, networking, and tangible rewards as the highest motivators. Older volunteers stated that they served out of commitment to the sport. At the Nordic Skiing Championship, younger people with lower incomes were motivated by the prospect of career enhancement while older people were motivated by their love for the sport (Wollebaek et. al., 2012). 
Volunteers at the 2010 Vancouver Olympic and Paralympic Games, who were characterized as older, employed individuals, were motivated to participate by the overall significance of the event (Dickson et. al., 2013).

\section{Volunteer Satisfaction}

Satisfaction with a specific volunteer experience is connected to positive perceptions of volunteering and intentions to serve as a volunteer in the future (Coyne and Coyne, 2001; Farrell et al., 1998; Green and Chalip, 2004). Volunteer satisfaction at sporting events has been examined from two perspectives. First, from consumer behavior researchers who propose that expectations play a role in determining satisfaction, satisfaction is defined as the difference between what one wants and what one gets from his/her job (Chelladurai, 2006). Locke (1967) and Oliver (1980) stated that satisfaction results from an evaluation of one’s experiences with an object, act, or circumstance and whether those experiences meet one's expectation. An example of this in sport research can be found in Bang and Ross (2009) who used two survey questions to determine volunteers' satisfaction (I am satisfied with the overall volunteer experience; I am happy with the experience I have gained). In mega sporting event experiences, volunteers are asked to give up large sums of time in order to make the event possible. Therefore, it is appropriate to examine satisfaction from the volunteers' view of their investment in relation to what they expect to gain from the experience.

Second, satisfaction has been examined from a psychological perspective, with self-determination theory being the foundation. Self-determination theory proposes that people have three inherent psychological needs: competence, relatedness, and autonomy 
(Deci and Vansteenkiste, 2004). Satisfaction of these needs is essential, but people do not always put themselves in situations to have these needs satisfied. Instead, people do what they find interesting and experience need satisfaction in participating in these endeavors (Deci and Vansteenkiste). From the self-determination theory perspective, individuals will be motivated to volunteer at a sporting event to the extent that they experience psychological need satisfaction. Two previous studies have examined the role of motivations on satisfaction of volunteers at sporting events. Elstad (1996) measured the determinants of satisfaction amid volunteers at the Lillehammer Winter Olympics Games. Results revealed the following factors were comparable to motives: expanding one’s personal network, being a part of the event, and achieving job related competence. Likewise, Bang and Ross (2009) found a positive relationship between three volunteer motives and satisfaction. The motives were Expression of Values (concern for others and success of the event) Career Orientation (gaining experience and making career contacts), and Love of Sport.

Purpose of the Study

The research on volunteer motivations at mega sporting events continues to evolve. While the aforementioned studies have provided important information about volunteer motives at special, large-scale sporting events, researchers have noted that mega sporting event volunteers may be drawn to assist with these happenings for very different reasons including their devotion to the sport, pride in their country, and pride in their community. The nature of the event itself may also be a unique motive for volunteers at mega sporting events. Therefore, it is important to consider the motives of volunteers for mega events separately, which was the first intent of this study. 
RQ1: What motivates individuals to volunteer at a mega sporting event?

The second intent of this study was to investigate differences in volunteer motivations based upon demographic characteristics. While it is well known that volunteer motivations are multidimensional, sport researchers have largely ignored the fact that motivations may vary by individual. Matching volunteers with their motivations, could assist in retention of volunteers as these experiences will meet the expectations of the volunteer and therefore increase the likelihood of repeating the volunteer experience (Treuren, 2014).

RQ2: Do volunteer motivations vary by gender, age, educational level, or income?

The third intent of this study was to understand any linkage between volunteer motivations and satisfaction. Previous research has recognized volunteer satisfaction as important to the success of the event and to volunteer recruitment and retention. However, satisfaction with volunteer experience may be dependent upon the motives of the volunteer. Thus, volunteer managers' effort to satisfy volunteers' motivation should focus on understanding what motivational factors most influence volunteer satisfaction (Farrell et. al., 1998).

RQ3: Does a volunteers' motivation predict satisfaction with the volunteer experience?

\section{Materials and Method}

This research was conducted using a modified version of the Volunteer Motivations Scale for International Sporting Events (VMS-ISE, Bang and Chelladurai, 2009). Members of the event's organizing committee, who were professional experts in the field, reviewed and approved questions used for the survey. The category, Extrinisic Rewards, was reduced to one question (I want to get event uniform/licensed apparel). The 
question "I want to get tickets/free admission" was removed as volunteers were not offered this option. The revised survey consisted of twenty-five questions. Nineteen items measured seven motivational categories including Values, Community Involvement, Interpersonal Contacts, Career Orientation, Personal Growth, Extrinsic Rewards, and Love of Sport. Respondents ranked each motivation item using a Likert scale ranging from 1 (strongly disagree) to 5 (strongly agree). Additional survey items asked for the following sociodemographic information: gender, age, educational level, and income. One question measured volunteer satisfaction on a Likert scale ranging from 1 (not at all satisfied) to 5 (extremely satisfied).

The survey was administered via Survey Monkey one week after the conclusion

of the event. All 8,000 volunteers registered to work the event were invited to participate via the email address provided during volunteer registration. An email explaining the purpose of the study, along with a link to the questionnaire was sent to all volunteers. A reminder email was sent two weeks later in an attempt to maximize participation. The volunteers worked in a variety of operational areas for the event including ancillary events, parking, and transportation. None of these participants volunteered at the game itself. The survey took approximately 15 minutes to complete. This research provides one of the largest sample sizes to date for studying volunteer motivations at mega sporting events. Of the 8,000 persons who volunteered for this event, 1,928 (24\%) completed the questionnaire.

\section{Data Analysis}

Exploratory factor analysis was performed to reduce the 19 survey questions into a smaller number of factors. Maximum likelihood factor analysis with varimax rotation 
was utilized. Cronbach's alpha and correlations between factor scores were analyzed to ensure reliable and discriminate factors. Once the factors were identified, the factor scores were subjected to a multivariate analysis of variance (MANOVA) on the basis of four independent variables (gender, age, education, income) to examine difference between groups on the factors. Finally, multiple regression was used to predict satisfaction on the basis of the four factors identified in the factor analysis. Data were analyzed using SPSS Version 22.

\section{Results}

The first aim of the study was focused upon volunteers' motives to serve at the event. Participants were asked to respond to 19 items that influenced their decision to serve at the event. Making the event a success $(M=4.73, S D=.516)$ was the highest rated among the 19 questions, while gaining career related experience $(\mathrm{M}=2.89, S D=$ 1.137) was the lowest. Ten items were rated in the 4.0-5.0 range, seven items were rated in the 3.0-4.0 range, and two items were rated below 2.99. Correlations between the 14 items were all less than .7, establishing discriminate validity between questions.

$<$ Insert Table 1 about here $>$

\section{Factor Analysis}

The factor analytic technique was then employed to identify the underlying patterns of relationships embedded in the data. The dimensionality of the 19 items from the volunteer survey were analyzed using maximum likelihood factor analysis. Three items (I want to get event uniform/licensed apparel, I want to meet new people, I want to interact with others) were removed due to communality values less than .4. Upon removing these variables, it was determined that factor scores were not correlated, 
indicating that Varimax rotation was the appropriate orthogonal rotation to be selected. Next, two items (I want to do something worthwhile, Volunteering allows me to gain a new perspective) were removed because they loaded on two components with factor loadings greater than .4. As a result, the remaining 14 items loaded onto four factors that possessed eigenvalues greater than 1 . The remaining items loaded above .4 on one of the four factors and were included in the final solution. The final rotated solution with 14 items loading onto four factors is presented in Table 2.

$<$ Insert Table 2 about here $>$

The four factors, which collectively explained $56.4 \%$ of the total variance, were labeled Community Support (29.3\% of variance), Career Development (11.6\% of variance), Personal Growth (9.9\% of variance), and Love of Sport (5.6\% of variance). The Kaiser-Meyer-Olkin measure of sampling adequacy was adequate at .836. Crombach’s alpha values exceeded .7 for each factors, indicating acceptable scale reliability. Community was the highest rated factor $(M=4.59, S D=.49, \alpha=.817)$, followed by Love of Sport $(M=3.95, S D=.91, \alpha=.797)$, Personal Growth $(M=3.87$, $S D=.81, \alpha=.795)$, and Career Development $(M=3.09, S D=.97, \alpha=.795)$.

Discriminate validity was established between the factors by examining the bivariate correlations between the factor scores (Kline, 2005). All correlations were less than 0.10.

The second aim of the study was to investigate differences in motivations to volunteers at a mega event based upon various demographic characteristics. Differences in motivations based upon volunteers' gender, age, education level, and income were examined. Factor scores were utilized to examine the difference between demographic groups (gender, age, income, education) on the four factors generated by the factor 
analysis using a two-way 4 by 4 factorial MANOVA. Descriptive statistics for the four independent variables are listed in Table 3.

$<$ Insert Table 3 about here $>$

\section{MANOVA}

Results indicated that differences in motivations depending on gender existed. The differences between groups on the combined dependent variables were statistically significant for each independent variable (see Table 4). Follow-up univariate ANOVAs in Table 5 showed that gender was statistically significantly different on Community and Love of Sport. Age was significantly different on Community, Career, and Love of Sport. Education was significantly different on Career and Growth. Finally, income was significantly different on Community, Career, and Growth.

$<$ Insert Tables 4 and 5 about here $>$

Examination of parameter estimates and LSD post-hoc tests revealed specific group differences. A summary of LSD post-hoc tests is presented in Table 6. First, for gender, females rated Community higher than males $(t=3.433, p<.001)$, and males rated Love of Sport higher than females $(t=4.867, p<.001)$.

Second, for age, Community became more important as volunteers increased in age. Volunteers under 30 years old rated Community lower than all other age groups. Likewise, volunteers over 60 years old rated Community higher than volunteers under 40 years old. In contrast, Career was more important to younger volunteers. Volunteers under 30 rated Career higher than all other age groups and volunteers over 60 rated Career lower than all other age groups. Additionally, volunteers in their 30s rated Career higher than volunteers in their 50s and 60s. Finally, volunteers under 30 and over 60 
generally rated Love of Sport higher than other age groups. Volunteers under 30 rated Love of Sport higher than all other age groups except over 60 . Volunteers over 60 rated Love of Sport higher than those in their 30s and 50s.

Third, for education level, volunteers without a college degree rated Career higher than those with a bachelor's degree and those with a graduate degree, and volunteers with a bachelor's degree rated Career higher than those with a graduate degree. Additionally, volunteers without a college degree rated Growth higher than those with a bachelor's degree and those with a graduate degree.

Fourth, for income level, Community motives increased as annual household income increased. Volunteers with an annual household income over $\$ 100,000$ rated Community higher than those at lower income levels. In contrast, Career motives increased as annual household income decreased. Volunteers with an annual household income less than $\$ 40,000$ rated Career higher than those at higher income levels, and volunteers making between $\$ 40,000$ and $\$ 99,000$ rated Career higher than those making over $\$ 100,000$. Likewise, Growth motives increased as annual household income decreased. Volunteers with an annual household income greater than $\$ 100,000$ rated Growth lower than those at lower income levels, and volunteers making between $\$ 40,000$ and $\$ 99,000$ rated Growth higher than those making over $\$ 100,000$.

$<$ Insert Table 6 about here $>$

\section{Multiple Regression}

The third aim of the study was to investigate the relationship between volunteers' motives for serving and their level of satisfaction with their experience. Participants were asked to rate their overall satisfaction with the volunteer experience. Satisfaction was 
measured with one question on a 1-5 (1 indicated very unsatisfied, 5 indicated very satisfied) Likert-type scale, "Rate your satisfaction with your overall volunteer experience” $(M 4.49, S D=.734)$. In general, volunteers were satisfied with their experience. The four variables from the factor analysis were utilized to predict satisfaction. All four variables were statistically significantly in predicting satisfaction, $F(4,1779)=25.84, p<.001$ adj. $\mathrm{R}^{2}=.053$. All four variables added statistically significantly to the prediction, $p<.05$.

\section{$<$ Insert Table 7 about here $>$}

\section{Discussion}

This study examined volunteer motivations at the United States’ largest mega sporting event, the NFL Super Bowl. The aims of this study were to investigate volunteers’ motives for serving at a mega-event, differences in motivations based upon volunteers’ demographic characteristics (e.g., gender, age, education level, income), and the relationship between volunteers' motives for serving and their satisfaction with the volunteer experience. Because the success of sporting events largely relies on volunteer assistance, it is very important for event organizers and volunteer coordinators to understand the reasons why volunteers elect to lend their efforts in order to help execute an event. Furthermore, it is also important to learn of motivations that attract volunteers of various demographics so that a volunteer pool that can best execute necessary tasks can be assembled. Finally, event organizers should attempt to gain information with regard to volunteer satisfaction resulting from fulfillment of motives in order to aid in the process of recruiting and retaining volunteers for subsequent events. 
Similar to other mega events, the top motives for volunteering were related to expressing pride in the community and making the event a success (as found by Strigas and Jackson,2003, Twynam et. al., 2003, Bang and Chelladurai, 2009, and Bang and Ross, 2009). These results reveal the strength of civic pride among these volunteers, with a primary focus on what they give to the community versus what they personally gain from the experience. Past research has found that simply being a citizen of a hosting city or region and volunteering in a mega-event is a source of pride and prestige, which are key components of the Community Support factor identified in this study (Kim, Kim, \& Odio, 2010). As a result of these findings, personnel in charge of recruiting volunteers should put emphasis on the contributions volunteers can make with regard to enhancing their community's image when recruiting, selecting and training volunteers.

A secondary motive was the opportunity to use this event to enhance one's career. Perhaps the large number of volunteers involved with the event $(8,000)$, the variance in activities associated with the event, and the prominence of the event in the community provided volunteers with the idea that working the event would enhance their resume. Career related motives were strongest among volunteers 30 years of age or less as this is a demographic attempting to gain access to the sport management field for the first time. Better positioning oneself for employment opportunities was important to this demographic; therefore, volunteer coordinators seeking assistance from this demographic should strongly emphasize the career enhancement opportunities associated with volunteering.

Finally, Love of Sport was the lowest ranked of the four motivating factors. This is interesting considering that the NFL is currently the most popular professional sports 
league in the United States. Perhaps volunteers were well informed in advance that they were not going to get to see the game as a part of their responsibilities, an aspect identified by others who found Love of Sport to be a primary motivator (MacLean and Hamm, 2007; Giannoulakis, et. al., 2008)

A distinctive aspect of this study was the recognition that mega sport volunteers are not a uniform group. Ten of the sixteen group comparisons showed significant differences between groups. Career enhancement opportunities were important for volunteers in three categories: age, educational level, and income. An inverse relationship was discovered between career enhancement as a motivator and both the level of education and the income of the volunteer (as found by Wollebaek et. al., 2012). Younger volunteers indicated career enhancement as a primary motive more often than older volunteers (as found by Jarvis and Blank, 2011; Wollebaek, et. al.). Likewise, Love of Sport was found to differ by gender, with males ranking it higher than females.

Unique to this study was the discovery of a common motivator shared by two age groups. Love of Sport was ranked highly by both volunteers under the age of 30, and volunteers over the age of 60 . Also, older volunteers were motivated by pride in the community and a desire to raise the prestige of the community instead of commitment to the sport, as reported by Jarvis and Blank (2011). Another unique finding was the discovery of a relationship between two volunteer characteristics and two other motivators, Community Involvement and Personal Growth. A significant difference in Community Involvement motives was found when income was a defining characteristic. Community Involvement motives fluctuated with income, increasing as annual household income increased. Given the fact that career motives increased as incomes decreased, this 
finding is not surprising. A difference in Personal Growth as a motivator was found with two characteristics, income and educational level. Personal Growth was a stronger motivator for volunteers without a college degree when compared to those holding bachelor's or graduate degrees. Personal Growth was also a stronger motivator for those with lower incomes. Volunteers with lower incomes were most strongly motivated by the Personal Growth and Career Enhancement opportunities that volunteering at a mega sporting event provides.

The last aim of this study was to investigate the potential of a volunteer's motives to predict satisfaction with the experience. The regression analysis revealed all four motivational variables predicted satisfaction among volunteers. These results are consistent with previous research in finding that Love of Sport and the opportunity to enhance one's career are motivational factors that influence volunteer satisfaction (Bang and Ross, 2009; Elstad, 1996). However, the impact of Personal Growth and Community Support are new to the mega sport event literature. The desire to raise the prestige of the city through the Super Bowl may stem from the fact that this was the first time this city had hosted the Super Bowl. Media coverage starting at the time the city was awarded the bid and leading up to the event emphasized the event's ability to enhance the perception of the city. Likewise, the importance of Community Support in this study confirmed media accounts that highlighted the civic pride that volunteers from central Indiana demonstrated by volunteering for the Super Bowl (Jarocz, 2012; Tully, 2014). According to Mike Karnuta, director of $\mathrm{x}$ for the Indiana Sports Corporation, "When someone volunteers for a major sporting event where fans/guests are coming in from out of town, like the 2012 Super Bowl, they access a rare opportunity. The volunteer gets 
to take on a dual identity. They get to become...an 'ambassador'. It is a chance for them to not only help and serve the event in a defined role, but they also get to share their love for their hometown with visitors. Indianapolis' volunteers take that responsibility seriously and some have commented that Indy's has 'professional volunteers'. Call it what you want. It has been my experience that their 'professionalism' is largely driven by civic pride and a desire to create a guest experience." Therefore, this link between Community Involvement and satisfaction could be anticipated.

\section{Conclusion}

This study focused upon investigating volunteer motivations and the relationship between fulfillment of motivations and satisfaction with the experience. Using one of the largest sample sizes to date, this research identified two main motives for volunteering for the NFL Super Bowl, pride in the community and making the event a success, verifying the significance of purposive motives among mega event volunteers This study also discovered that motivations are different based upon the gender, age, economic status, and educational level of the volunteer.

Both the organizers of the event as well as those who volunteer to assist at the event could receive numerous benefits as a result of the volunteer/event relationship. In order for a mutually beneficial relationship to evolve, however, alignment must exist between the motives of the volunteer and experience the volunteer experience provides. Personnel charged with the responsibility should make attempts to understand the reasons why volunteers are interested in serving at their event prior to hiring. Motivations could be obtained through a questionnaire included as part of a volunteer application. 
Understanding volunteer motivations and the differences between groups of people will allow event managers to develop management practices that may assist in volunteer performance. Hallman and Harms (2012) and Bang \& Ross (2009) advocated that event managers seek to find a match between volunteer motivations and volunteer tasks. Identifying motivational differences based upon gender, age, educational background, and economic status allows event mangers to write volunteer job descriptions that speak to the various motivations. This, in turn, will allow volunteers to be assigned to or choose tasks that tap into their desires, thus enhancing volunteer satisfaction.

For example, if a potential volunteer is motivated by career enhancement and expresses interest in volunteering because s/he views the experience as a way to gain valuable skills that will increase his/her marketability in an employment search, volunteer management personnel should attempt to place that person into positions that would allow them to build skills or be trusted to oversee tasks. Therefore, they could be more likely to be more excited about their position and perform better. Consequently, the event stands to gain because a motivated volunteer who has something to gain through the experience would likely perform his/her tasks effectively. The volunteer stands to gain because s/he is gaining relevant experience that could be desirable to future employers. This could ultimately lead to successful implementation of the event.

It should be recognized that attempting to align thousands of volunteers with their own motives would be a difficult task; however, any efforts made by volunteer coordination personnel would be beneficial; therefore, these attempts are encouraged whenever possible. In summation, satisfied volunteers, like satisfied employees, are more 
willing to show up, complete their required tasks, and come back to volunteer in the future. Future research should consider the link between volunteer motives, satisfaction, retention, and management practices.

In addition, knowledge of motives and satisfaction among volunteers could be useful in the creation of marketing materials used in the process of volunteer acquisition. Through the discovery of motivational differences among volunteers of various demographics, targeted recruiting materials, as suggested by Hallman and Harms (2012), could be created. Future research should investigate the use and effectiveness of targeted marketing materials and messaging in volunteer recruitment and retention.

Finally, this research did not focus upon personality or other lifestyle characteristics of volunteers, which may influence motivation, satisfaction, and retention. Therefore, investigating these factors to further ascertain volunteer motivations and intent to volunteer again would be appropriate, as retention is important to volunteer managers and event coordinators. While this study did confirm the linkage between certain volunteer motivations and satisfaction it is likely that dissatisfied volunteers chose not to participate in this study. Since volunteers who had a positive and satisfying experience are more likely to participate in the study, the possibility that these findings might be overly positive exists. Since it is suspected that only satisfied volunteers took the time to respond to the study, these results may not fully capture the relationship between satisfaction and volunteer motivations. 


\section{References}

Bang, H. and Ross, S. (2009), "Volunteer motivation and satisfaction”, Journal of Venue and Event. Management, Vol. 1 No. 1, pp. 61-77.

Bang, H. and Chelladurai, P. (2009), “Development and validation of the volunteer motivations scale for international sporting events (VMS-ISE)”, International Journal of Sport Management and Marketing, Vol. 6 No. 1, pp. 332-350.

Chelladurai, P. (2006). Human resource management in sport and recreation 2nd ed. Champaign: Human Kinetics.

Coyne B.S. and Coyne, E.J., Sr. (2001), “Getting, keeping and caring for unpaid volunteers for professional golf tournament events”, Human Resource Development International, Vol. 4, pp. 199-216.

Deci, E.L. and Vansteenkiste, M. (2004), "Self-determination theory and basic need satisfaction: Understanding human development in positive psychology”, Richerche di Psicologia, Vol. 1 No. 27, pp. 23-39.

Dickson, T.J., Benson, A.M., Blackman, D.A., and Terwiel, F.A. (2013), “It’s all about the games! 2010 Vancouver Olympic and Paralympic winter games volunteers”, Event Management, No. 17 No. 1, pp. 77-92.

Doherty, A.J. (2009), "The volunteer legacy of a major sport event, journal of policy research in tourism”, Leisure and Events, Vol. 1 No. 3, pp. 185-207.

Downward, P., Lumsdon, L., and Ralstion, R. (2005), “Gender differences in sport event volunteering: Insights from Crew 2002 at the XVII Commonwealth Games”, Managing Lesisure, Vol. 10 No. 4, pp. 219-236.

Elstad, B. (1996), "Volunteer perception of learning and satisfaction in a mega-event: the case of the XLVII Olympic Winter Games in Lillehammer", Festival Management and Event Tourism, Vol. 4 No. 3/4, pp. 75-86.

Farrell, J.M., Johnson, M.E., and Twynam, G.D. (1998), "Volunteer motivation, satisfaction, and management at an elite sporting competition”, Journal of Sport Management, Vol. 12 No. 4, pp. 181-202.

Georgiadis, T., Spiliopoulos, P., Rampotas, C., and Rampotas, G. (2006), "Motivation and volunteer participation in the Athens 2004 Olympic Games. Choregia, Vol. 2 No 1, pp. 65-89. 
Giannoulakis, C., Wang., C. and Gray, D. (2008), "Measuring volunteer motivation in mega-sporting events”, Event Management, Vol. 11 No. 4, pp. 191-200.

Green, B.C. and Chalip, L. (1998), “Sport volunteers: Research agenda and application”, Sport Marketing Quarterly, Vol. 7, pp. 371-485.

Green, B.C. and Chalip, L. 2004, "Paths to volunteer commitment: Lessons from the Sydney Olympic Games”, in: Stebbins, R. A. and Graham, M. (Eds.), Volunteering as Leisure/Leisure as Volunteering: An International Assessment. Cambridge, MA: CABI publishing, pp 49-67.

Hallman, K. and Harms, G. (2012), "Determinants of volunteer motivation and their impact on future voluntary engagement. A comparison of volunteer's motivation at sport events in equestrian and handball”, International Journal of Event and Festival Management, Vol. 3 No. 3, pp. 272-291.

Hiller, H. H. (2000), "Mega-events, urban boosterism, and growth strategies: An analysis of the objectives and legitimations of the Cape Town 2004 Olympic Bid” International Journal of Urban and Regional Research, Vol. 24 No. 2, pp. 439-458.

Horne, J. (2007), “The four 'knowns' of sports mega-events” Leisure Studies, Vol. 26 No. 1, pp. 81-96.

Jarosz, F. (2012), “Throng of volunteers involved in staging Super Bowl,” Indianapolis Business Journal, 7 Jan., Vol. 32 No. 46, pp. 1A-26A. 2p.

Kim, M., Kim, M.K., \& Odio, M.A. (2010), “Are you proud? The influence of sport and community identity and job satisfaction on pride of mega-event volunteers”, Event Management, Vol. 14 No. 2, pp. 127-136.

Locke, E. A. (1967), "Relationship of success and expectation to affect on goal seeking tasks”, Journal of Personality and Social Psychology, Vol. 7 No. 2, pp. 125-134.

MacLean, J. and Hamm, S. (2007), "Motivation, commitment, and intentions of volunteers at a large Canadian sporting event”, Leisure/Loisir, Vol. 31 No. 2, pp. 523556.

Malfas, M., Theodoraki, E., and Houlihan, B. (2004), "Impacts of the Olympic Games as mega-events”, Municipal Engineer, Vol. 15 No. 3, pp. 209-220.

Oliver, R. L. (1980), “A cognitive model of the antecedents and consequences of satisfaction decisions”, Journal of Marketing Research, Vol. 17 No. 4, pp. 460-469.

Pauline, G. (2011), "Volunteer satisfaction and intent to remain: An analysis of contributing factors among professional golf volunteers", International Journal of Event Management Research, Vol. 6 No. 1, pp. 10-32. 
Pauline, G and Pauline, J. (2009), "Volunteer motivation and demographic influences at a professional tennis event”, Team Performance Management, Vol. 15 No. 3/4, pp. 172184.

Shin, S. and Kleiner, H. (2003), "How to manage unpaid volunteers in organizations”, Research News, Vol. 26 No. 2/3/4, pp. 63-67.

Strigas, A.D. and Jackson, E.N. (2003), “Motivating volunteers to serve and succeed: design and results of a pilot study that explores demographics and motivational factors in sport volunteerism”, International Sports Journal, Vol. 7 No. 1, pp. 111-124.

Treuren G. (2014), "Enthusiasts, conscripts or instrumentalists? The motivational profiles of event volunteers”, Managing Leisure, Vol. 19, No. 1, pp. 51-70.

Tully, M. (2014). “A second Super Bowl? First game still resonates”. Indianapolis Star, 18 May, pp. A.1.

Twynam, G.D., Farrell, J.M., and Johnston, M.E. (2003), “Leisure and volunteer motivation at a special sporting event”, Journal of the Canadian Association for Leisure Studies, Vol. 27 No. 3.4, pp. 363-377.

Wollebaek, D., Skirstad, B., and Hanstad, D. (2012), "Between two volunteer cultures: Social composition and motivation among volunteers at the FIS Nordic World Ski Championships”, International Review for the Sociology of Sport, Vol. 49 No. 1, pp. 2241.

Van Riper, T. (2012), “How the London Olympics will recoup its costs: Happiness” available at: http://www.forbes.com/sites/tomvanriper/2012/08/08/how-the-londonolympics-will-recoup-its-costs-happiness (accessed 6 June 2013).

Woolley, S. and Steverman, B. (2012), “Cost of Super Bowl-dom” available at: http://www.bloomberg.com/consumer-spending/2012-02-02/the-real-cost-of-super-bowldom.html\#slide4 (accessed 5 September 2013).

Jarvis, N. \& Blank, C. (2011). The importance of tourism motivations among sport event volunteers at the 2007 World Artistic Gymnastics Championships, Stuttgart, Germany. Journal of Sport \& Tourism, Vol. 16 No. 2, pp. 129-147.

Kline, R. B. (1998). Principles and Practice of Structural Equation Modeling. New York, NY: Guilford.

Skirstad, B., \& Hanstad, D. (2013). Gender matters in sport event volunteering. Managing Leisure, Vol. 18 No. 4, pp. 316-330.

Tully (2014). 
I want to help make the event a success

I want to express my pride in my community

I feel it is important to help others

Volunteering creates a better society

I want to do something worthwhile

To raise the prestige of my community

I want to interact with others

Volunteering allows me to gain a new perspective on things

I want to meet new people

Volunteering makes me feel better about myself

I like any event related to sport

I want to develop working relationships with others

Volunteering makes me feel needed

I like any event related to this sport (football)

Volunteering makes me feel important

I want to gain some practical experience

I want to get event uniform/licensed apparel

Volunteer experiences will look good on my resume

Volunteering helps me gain career-related experience
4.73

4.63

4.59

4.58

4.50

4.43

4.40

4.25

4.16

4.04

3.98

3.98

3.94

3.92

3.62

3.43

3.00

2.93

2.89
0.516

0.612

0.589

0.600

0.623

0.838

0.764

0.759

0.833

0.874

0.959

0.904

0.985

1.027

1.036

1.131

1.201

1.185

1.137

Table 1 Mean and SD of survey items 
Factor 1 - Community Support

Express pride in community

0.826

Help make the event a success

0.729

Important to help others

0.678

Volunteering creates a better society

0.656

Raise prestige of community

0.579

Factor 2 - Career Development

Gain career-related experience

0.814

0.700

Gain practical experience

0.681

Volunteering looks good on resume

0.485

Factor 3 - Personal Growth

Volunteering makes me feel important

0.718

Volunteering makes me feel needed

Volunteering makes me feel better about myself

Factor 4 - Love of Sport

I like any event related to sport

I like any event related to this sport (football)

Note: Extraction method: Maximum Likelihood; Rotation method: Varimax 


\section{Gender}

Age

Male

Female

Under 30

$30 \mathrm{~s}$

$40 \mathrm{~s}$

$50 \mathrm{~s}$

Over 60

Education

No college degree

Bachelor's degree

Graduate degree

Less than $\$ 40,000$

$\$ 40,000-\$ 99,999$

Over $\$ 100,000$
542

1,202

157

293

503

500

291

603

665

476

401

658

685

Table III Descriptive statistics for demographic variables 
Variable

Wilks $\lambda$
9.795

7.373

9.130

7.359

4

16

0.959

0.967
8

8
0.001

0.001

0.001

0.001

Table IV Multivariate test 
Independent variable

Gender

Age

Education

Income
Dependent variable

Community

Career

Growth

Sports

Community

Career

Growth

Sports

Community

Career

Growth

Sports

Community

Career

Growth

Sports

\section{MS}

9.580

0.319

1.919

19.506

3.727

13.796

1.112

2.477

0.959

20.732

3.975

0.863

5.603

11.774

2.259

1.666
F

11.789

0.452

2.696

23.691

4.586

19.579

1.563

3.009

1.180

29.425

5.584

1.049

6.895

16.710

3.174

2.023 df

0.001

0.501

0.101

0.001

0.001

0.001

0.182

0.017

0.307

0.001

0.004

0.351

0.001

0.001

0.042

0.133

Table $\mathbf{V}$ Test of between-subject effects 


\begin{tabular}{|c|c|c|c|c|c|}
\hline $\mathrm{V}$ & DV & Category 1 & Category 2 & Mean difference (Cat. 1-Cat. 2) & $p$ \\
\hline \multirow[t]{6}{*}{ Education } & \multirow[t]{3}{*}{ Career } & \multirow[t]{2}{*}{ No college degree } & Bachelors & 0.16 & 0.001 \\
\hline & & & Graduate & 0.50 & 0.001 \\
\hline & & Bachelors & Graduate & 0.33 & 0.001 \\
\hline & \multirow[t]{3}{*}{ Growth } & \multirow[t]{2}{*}{ No college degree } & Bachelors & 0.19 & 0.001 \\
\hline & & & Graduate & 0.19 & 0.001 \\
\hline & & Bachelors & Graduate & 0.00 & 0.967 \\
\hline \multirow[t]{9}{*}{ Income } & \multirow[t]{3}{*}{ Community } & \multirow[t]{2}{*}{ Less than $\$ 40,000$} & $\$ 40,000-99,999$ & -0.09 & 0.102 \\
\hline & & & Over $\$ 100,000$ & -0.23 & 0.001 \\
\hline & & $\$ 40,000-99,999$ & Over $\$ 100,000$ & -0.15 & 0.003 \\
\hline & \multirow[t]{3}{*}{ Career } & \multirow[t]{2}{*}{ Less than $\$ 40,000$} & $\$ 40,000-99,999$ & 0.23 & 0.001 \\
\hline & & & Over $\$ 100,000$ & 0.48 & 0.001 \\
\hline & & $\$ 40,000-99,999$ & Over $\$ 100,000$ & 0.25 & 0.001 \\
\hline & \multirow[t]{3}{*}{ Growth } & \multirow[t]{2}{*}{ Less than $\$ 40,000$} & $\$ 40,000-99,999$ & 0.08 & 0.127 \\
\hline & & & Over $\$ 100,000$ & 0.20 & 0.001 \\
\hline & & $\$ 40,000-99,999$ & Over $\$ 100,000$ & 0.12 & 0.009 \\
\hline \multirow[t]{30}{*}{ Age } & \multirow[t]{10}{*}{ Community } & \multirow[t]{4}{*}{ Under 30} & $30 \mathrm{~s}$ & -0.19 & 0.029 \\
\hline & & & $40 \mathrm{~s}$ & -0.31 & 0.001 \\
\hline & & & $50 \mathrm{~s}$ & -0.32 & 0.001 \\
\hline & & & Over 60 & -0.37 & 0.001 \\
\hline & & \multirow[t]{3}{*}{$30 \mathrm{~s}$} & $40 \mathrm{~s}$ & -0.11 & 0.087 \\
\hline & & & $50 \mathrm{~s}$ & -0.13 & 0.054 \\
\hline & & & Over 60 & -0.18 & 0.014 \\
\hline & & \multirow[t]{2}{*}{$40 \mathrm{~s}$} & $50 \mathrm{~s}$ & -0.01 & 0.803 \\
\hline & & & Over 60 & -0.07 & 0.298 \\
\hline & & $50 \mathrm{~s}$ & Over 60 & -0.05 & 0.409 \\
\hline & \multirow[t]{10}{*}{ Career } & \multirow{4}{*}{ Under 30} & $30 \mathrm{~s}$ & 0.46 & 0.001 \\
\hline & & & $40 \mathrm{~s}$ & 0.53 & 0.001 \\
\hline & & & $50 \mathrm{~s}$ & 0.62 & 0.001 \\
\hline & & & Over 60 & 0.80 & 0.001 \\
\hline & & \multirow[t]{3}{*}{$30 \mathrm{~s}$} & $40 \mathrm{~s}$ & 0.07 & 0.234 \\
\hline & & & $50 \mathrm{~s}$ & 0.17 & 0.007 \\
\hline & & & Over 60 & 0.27 & 0.001 \\
\hline & & \multirow[t]{2}{*}{$40 \mathrm{~s}$} & $50 \mathrm{~s}$ & 0.09 & 0.081 \\
\hline & & & Over 60 & 0.27 & 0.001 \\
\hline & & $50 \mathrm{~s}$ & Over 60 & 0.18 & 0.004 \\
\hline & \multirow[t]{10}{*}{ Sports } & \multirow[t]{4}{*}{ Under 30} & $30 \mathrm{~s}$ & 0.33 & 0.001 \\
\hline & & & $40 \mathrm{~s}$ & 0.21 & 0.010 \\
\hline & & & $50 \mathrm{~s}$ & 0.30 & 0.001 \\
\hline & & & Over 60 & 0.16 & 0.069 \\
\hline & & $30 \mathrm{~s}$ & $40 \mathrm{~s}$ & -0.12 & 0.080 \\
\hline & & & $50 \mathrm{~s}$ & -0.03 & 0.671 \\
\hline & & & Over 60 & -0.17 & 0.026 \\
\hline & & $40 \mathrm{~s}$ & $50 \mathrm{~s}$ & 0.09 & 0.123 \\
\hline & & & Over 60 & -0.05 & 0.449 \\
\hline & & $50 \mathrm{~s}$ & Over 60 & -0.14 & 0.038 \\
\hline
\end{tabular}


Community

\section{Career}

Growth

Sports

Constant $\begin{array}{ll}0.152 & 0.017\end{array}$

$\begin{array}{ll}0.048 & 0.019\end{array}$

0.075

0.046

4.482
0.188

0.058

0.087

0.057
0.001

0.012

0.001

0.013

0.001

Table VII Multiple regression predicting satisfaction 